\title{
Short-Term Impact of Drip Irrigation Frequency on Soil Hydro-Physical Properties of an Alfisol and Performance of Two Maize Varieties
}

\author{
Awe Gabriel Oladele ${ }^{1, a}$, Ayuba Margret Busola ${ }^{1, b}$, Umam Japhet $^{1, c}$, Abegunrin Toyin Peter ${ }^{\text {,d,* }}$ \\ ${ }^{1}$ Department of Soil Resources and Environmental Management, Faculty of Agricultural Sciences, Ekiti State University, PMB 5363, Ado \\ Ekiti, Ekiti State, Nigeria \\ ${ }^{2}$ Department of Agricultural Engineering, Ladoke Akintola University of Technology, Ogbomoso, Oyo State, Nigeria \\ *Corresponding author
}

A R T I C L I N F O A B S T R A T

Research Article

Irrigation scheduling is important for efficient use of applied water and for maximizing crop yields. Therefore, the aim of this study was to evaluate the short-term effect of drip irrigation frequency on soil hydro-physical properties of an Alfisol and performance of two maize varieties, at the Teaching and Research Farm, Faculty of Agricultural Sciences, Ekiti State University, Ado Ekiti, Southwest

Received : 24/03/2020

Accepted : 01/06/2020 Nigeria. The experiment was laid out using a split-plot experiment in randomized complete block design (RCBD) and three replications. Irrigation frequency constituted the main plot namely: irrigation four times a week (I4), irrigation thrice a week (I3), and irrigation twice a week (I2) of re-filling soil to field capacity while the subplot was maize variety namely: V1: SAMMAZ-27 and V2: OBA-super-6. Plant growth parameters and soil physical properties of soil water content (SWC), bulk density (BD) and saturated hydraulic conductivity (Ksat) were monitored during the

Keywords:

Irrigation scheduling Soil physical properties Growth parameters and yield Irrigation-variety interaction Ekiti State University growing cycle. Water use efficiency (WUE) and yield components were determined at maturity. There were significant interactions between irrigation regime and maize variety on SWC and Ksat. The maximum bulk density (BDmax) and optimum soil water content SWCopt were $1.41 \mathrm{~g} / \mathrm{cm}^{3}$ and $0.12 \mathrm{~g} / \mathrm{g}$, respectively. Plant height $(\mathrm{PH})$ did not differ between the two maize varieties throughout the growth cycle. Drip irrigation frequency did not significantly affect plant height until growth stage V12 (12 fully opened leaves), with I4 irrigation treatment having the tallest plant. Both drip irrigation and maize variety had no significant influence on both LAI and CC, neither was there any significant interaction effect. Increasing irrigation water increased maize yield and yield components. The treatment combination of I4V1 had the highest performance indices in terms of yield components. WUE decreased with increasing frequency of irrigation water application while the WUE of SAMMAZ-27 > OBA-super-6. Therefore, irrigating four times a week and SAMAZ27 maize variety could be a suitable irrigation-variety combination for providing sustainable irrigation agriculture for maize in this region.

\section{Introduction}

Maize (Zea mays) is the most important plant in the world. It is cultivated for both human (grain) and animal (grain and forage) consumption. In terms of global production, maize is the third most important cereal crop after wheat and rice (USDA, 2011). In Nigeria, maize has extensive adaptation characters and it is intensively cultivated. Although the land area cultivated with maize is increasing, the total production of maize is not sufficient to meet demand. Thus, the attempt to increase maize production has become of great importance.

Water is the most important limiting factor for agriculture and it has been a major problem in crop performance. Uneven and erratic rainfall distribution over the years, caused by climate change, has been a major factor responsible for water shortages in the tropics. Maize is very sensitive to water stress and the unavailability of water has been reported to limit maize production throughout the growth stages (Cakir, 2004; Payero et al., 2006; El-Hendawy et al., 2008; Kuscu and Demir, 2013). Payero et al. (2006) reported that soil moisture stress during any of the plant growth cycle can cause a reduction in growth and yield. El-Hendawy et al. (2008) reported that water stress due to low irrigation frequencies of only once in 4- and 5-days resulted in significant maize yield reduction of $22 \%$ and $72 \%$, respectively compared to irrigation once in 2 days. Water unavailability limits corn growth by way of reducing the uptake of macronutrients (Gutierrez et al., 2008). Therefore, strategies are needed to overcome the reduction of production and to increase efficiency. One of such approaches is irrigation, especially 
the drip irrigation system which has many advantages over other irrigation systems (Deshmukh and Hardaha, 2014; Awe et al., 2017). Abd El-Hafez et al. (2001) reported that drip irrigation method increased field and crop water use efficiencies of maize crops in clay soil by $35 \%$ and $9.52 \%$, respectively, as compared to furrow irrigation. Abd ElWahed and Ali (2013) reported that the drip irrigation system gave maximum maize grain yield and water use efficiency compared to the sprinkler irrigation system. ElHendawy et al. (2008) evaluated the response of two maize hybrid varieties under four levels of drip irrigation (2, 3, 4 and 5 irrigations per week). The results indicate that drip irrigation frequency did affect soil water content and retained soil water, depending on soil depth. The effect of irrigation frequency on grain yield was highly significant as the maximum yields were recorded at irrigation frequency once every 2 and 3 days. Water use efficiency (WUE) increased with increasing irrigation frequency, and reached the maximum values at once every 2 and 3 days. The authors recommended that irrigation frequency should be once every 2 or 3 days for optimum maize production.

Irrigation water scheduling is very crucial to make the most efficient use of a drip irrigation system, as excessive irrigation decreases yield, while insufficient irrigation causes water stress and reduces production. On the other hand, the intensity of the operation requires that the soil water supply be kept at the optimal level to maximize returns to the farmer (Sezen et al., 2007). Therefore, the frequency of water application has become an important factor in drip irrigation management (Coelho and Or, 1999; Assouline, 2002; Wang et al., 2006). Due to this phenomenon of irrigation frequency, water use efficiency (WUE) and crop yields may be different under different irrigation frequencies although the same quantity of water is applied. Wang et al. (2005) and Awe et al. (2016) found that reducing the frequency of water application resulted in a significant reduction in crop yield but increased WUE.

The introduction of irrigation to the soil could lead to fundamental changes in physical properties and processes, such as placing stresses upon soil structure which affects the pore space, availability of water, nutrients and gaseous exchange (Hamblin, 1985) because irrigated soils experience rapid wetting and undergo more frequent alternate wetting and drying cycles compared to rain-fed agriculture (Currie, 2006). Evidence of soil structural changes, such as increased bulk density, under drip irrigation have been reported (Clark, 2004). Awe et al. (2016) reported that soil BD significantly increased under daily water application. Wang et al. (2005) and Chen et al. (2019) reported that drip irrigation regimes affected soil water distribution. In contrast, Abbas (2010) reported that irrigation level has no significant effect on soil physical properties of $\mathrm{BD}$, infiltration rate, saturated hydraulic conductivity and porosity.

Despite the great effort towards expanding the production of maize through the adoption of drip irrigation technologies in every State in Nigeria for ensuring the food security agenda, there is limited information as regards soil-plant reaction due to irrigation water application. Research is still incipient on the performance of maize and its varieties under drip irrigation as well as the quality status of the soil environment that receives water of varying qualities (Igbadun, 2012; Awe et al., 2017; Ezekiel et al., 2017). Such information are required to guide the farmers, irrigation engineers, soil scientists, water resources managers and policy makers when designing irrigation system not only for maize but other crops.

We hypothesized that the frequency of water application, variety and their interaction significantly influenced some soil physical properties, growth and yield of maize. Therefore, the aim of the study was to investigate the shortterm effect of drip irrigation frequency on soil hydrophysical properties of an Alfisol and the performance of two maize varieties in Ado Ekiti, southwest Nigeria.

\section{Material and Methods}

\section{Description of Experimental Site}

The study was conducted at the Teaching and Research Farm, Ekiti State University, Ado-Ekiti, Southwest Nigeria. The site is located on Longitude $4^{\circ} 45^{\prime}$ to $5^{\circ} 45^{\prime} \mathrm{E}$ and Latitude $7^{\circ} 15^{\prime}$ to $8^{\circ} 5^{\prime} \mathrm{N}$ at $434 \mathrm{~m}$ above sea mean level. It is located in the humid tropical climate characterized by distinct dry and wet seasons with a moderate mean annual rainfall of about $1367.7 \mathrm{~mm}$ while temperature is almost uniform throughout the year with little deviations from means $27^{\circ} \mathrm{C}$. The Soil of the study site belongs to the broad group of Alfisol, classified as Typic Kandipludalf (Soil Survey Staff, 2014) with top sandy-loam to clay texture (Fasina et al., 2005). The land has been under irrigation since 2009 prior to this study.

\section{Experimental Design and Treatments}

The experiment was a split-plot, laid out in a Randomized Complete Block Design (RCBD) with three replications. Irrigation frequency constituted the main plot comprising three irrigation regimes namely: very high I4four irrigations per week, I3- three irrigations per week and I2- two irrigations per week of bringing the soil to field capacity while the subplot was crop variety namely: V1 (Sammaz-27) and V2 (Oba-super-6). There are six (6) treatment combinations of I2V1, I2V2, I3V1, I3V2, I4V1, and $\mathrm{I} 4 \mathrm{~V} 2$, giving eighteen (18) plots in total.

Land Preparation, Field Layout and Installation of the Drip Irrigation System

The experimental site was prepared manually using hoes and unburied grasses were properly removed to ensure a clean field. Manure at the rate of $10 \mathrm{t} / \mathrm{ha}$ was incorporated during land preparation. There were 6 blocks and each block was divided into three experimental units, each plot was 1.5 by $3.5 \mathrm{~m}$ (Figure 1 ).

The drip irrigation system consists of a $3000 \mathrm{~L}$ tank, 25 mm diameter main pipes and sub-mains, end plugs, T-joints, rubber hose, gate valves, lateral cum drippers, pipe nipples and so on (figures $1 \mathrm{~b}$ and 1c). The main line delivered water from the tank to the sub-mains into the drip lines, while the emitters delivered water to the field at the rate of $4 \mathrm{~L} / \mathrm{hr}$.

\section{Planting and Field Management}

Three to five (3 - 5) seeds of maize were planted per hill on the prepared beds at a spacing of $30 \mathrm{~cm}$ by $90 \mathrm{~cm}$ using a planting depth of about $5 \mathrm{~cm}$. Seedlings were later thinned to two (2) plants per stand. Weeding was done manually by hoeing and physically uprooting of weeds as well as the use of herbicide (Atrazine). Insects/pests were controlled using insecticide (caterpillar-force) while birds were controlled by covering the entire experimental field with 1 -inch nets. 


\begin{tabular}{|l||l||l|}
\hline$I_{4 w} V_{1} R 1$ & $I_{4 w} V_{2} R 3$ & $I_{4 w} V_{1} R 2$ \\
\hline$I_{2 w} V_{2} R 2$ & $I_{2 w} V_{1} R 1$ & $I_{2 w} V_{2} R 3$ \\
\hline$I_{3 w} V_{1} R 3$ & $I_{3 w} V_{2} R 2$ & $I_{3 w} V_{1} R 1$ \\
\hline$I_{4 w} V_{2} R 2$ & $I_{4 w} V_{1} R 3$ & $I_{4 w} V_{2} R 1$ \\
\hline$I_{2 w} V_{1} R 3$ & $I_{2 w} V_{2} R 1$ & $I_{2 w} V_{1} R 2$ \\
\hline$I_{3 w} V_{2} R 1$ & $I_{3 w} V_{1} R 2$ & $I_{3 w} V_{2} R 3 \quad$ a) \\
\hline
\end{tabular}
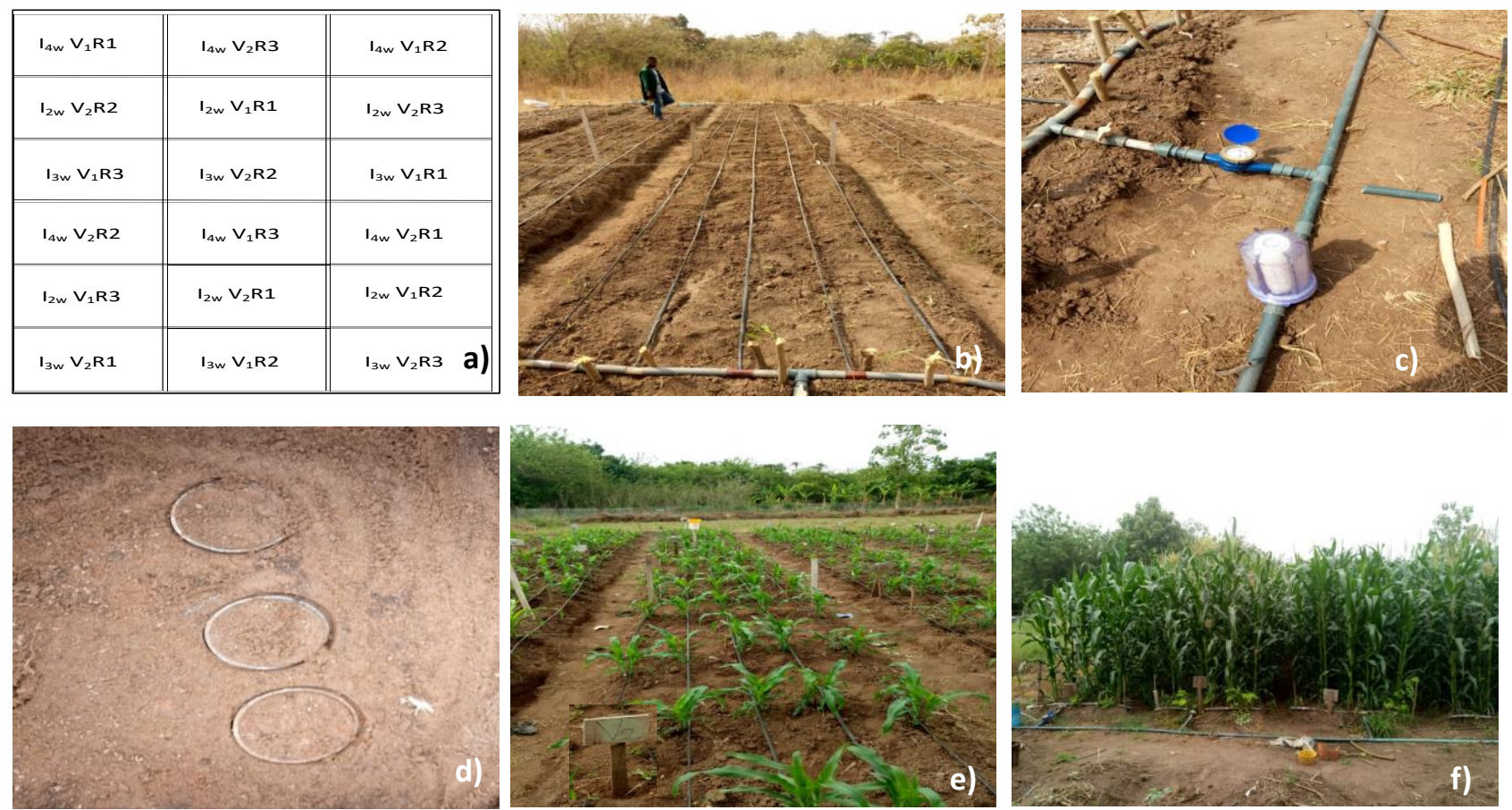

Figure 1. a) Experimental layout, b) seed bed and drip irrigation system installation, c) position of the filter and water meter, d) soil sampling, e) maize stands 3 fully opened leaf (V3) and f) maize at tasseling stage (VT).

\section{Soil Sampling and Analysis}

Before planting of maize, two representative profiles were dug within the experimental field and undisturbed soil samples were collected at different soil layers 0 - 20, 20 40, 40 - 60, 60 - 80, and 80 - $100 \mathrm{~cm}$ (Figure 1d) using core samplers made from metallic cylinders $(57 \mathrm{~mm}$ diameter and $40 \mathrm{~mm}$ high) for the determination of routine soil physical and chemical properties. The textural class of the soil was determined by the hygrometer method (Bouyoucous, 1962) and classified using the USDA soil texture classification. Sand and clay contents were used to estimate soil water content at field capacity (FC) and permanent wilting point (PWP) in the software SPAW (2020). The first sampling was done at the time of sowing and subsequent soil sampling campaigns were done by collecting samples from the $0-20 \mathrm{~cm}$ surface layer before and after each irrigation event in other to monitor soil water content, bulk density and saturated hydraulic conductivity. Samples for soil water content were collected in tin cans and samples for bulk density and saturated hydraulic conductivity were collected using core samplers.

\section{Data Collection}

\section{Soil water content}

The gravimetric method as described by Black et al. (1965) was used to determine the moisture content of the soil.

The soil moisture content was determined according to the equation

\section{Where;}

$$
\mathrm{SWC}=\frac{\mathrm{M}_{1}-\mathrm{M}_{2}}{\mathrm{M}_{2}}
$$

$\mathrm{SWC}=$ Soil water content, $\mathrm{g} \mathrm{g}^{-1}$

$\mathrm{M}_{1} \quad=$ Mass of wet soil $(\mathrm{g})$

$\mathrm{M}_{2} \quad=$ Mass of dry soil $(\mathrm{g})$

\section{Bulk density}

The undisturbed samples collected in core samplers were oven dried at $105^{\circ} \mathrm{C}$ for $48 \mathrm{~h}$ and the mass of the dry soil was determined (Blake and Hartge, 1986), the bulk density was evaluated from the equation;

Where;

$$
\mathrm{BD}=\frac{\mathrm{M}_{\mathrm{s}}}{\mathrm{V}}
$$

$\mathrm{BD}=$ Bulk Density $\left(\mathrm{g} / \mathrm{cm}^{3}\right)$

$\mathrm{Ms}=$ Mass of dry soil $(\mathrm{g})$

$\mathrm{V}=$ Volume of soil $\left(\mathrm{cm}^{3}\right)$

\section{Plant available water}

The plant available water in the $0-20 \mathrm{~cm}$ surface layer during the growing cycle was quantified considering the soil water content at field capacity (FC) as the upper limit and soil water content at the permanent wilting point as the lower limit. Soil water content above the FC is considered excess or gravity water and is not available for plant growth, also soil water content below PWP shows the soil is dry, such water is tightly held onto soil particles and not available for root extraction. Any water below the PWP is unavailable. So available water is soil water content at FC minus soil water content at PWP.

Growth Parameters, Yield and Yield Components

- Plant height: Plant height was measured using measuring tape from the soil surface to the highest point of the leaf whose tip is pointing down at plant growth stages V3, V9 and V12, corresponding to 3, 9 and 12 fully opened leaves (Ritchie et al., 1986).

- Leaf area/plant: The length and breadth of the leaf were measured using measuring tape and the leaf area/plant (A) was obtained during same growth stages described above using the relation following Saxena and Singh (1965).

$$
\mathrm{A}=0.75 \mathrm{~L} \times \mathrm{B}
$$

Where; $\mathrm{L}$ is the leaf length, $\mathrm{cm}, \mathrm{B}$ is leaf breadth, $\mathrm{cm}$. 
- Leaf area index and canopy cover: To estimate the leaf area index (LAI) and canopy cover (CC), digital photographs were taken at about $20 \mathrm{~cm}$ above the crop canopy using a hand-held digital camera with high resolution. The camera was positioned and held vertically (at about $20 \mathrm{~cm}$ from plant top) above the canopy and photographs were carefully taken. This procedure was repeated at three locations per plot. At the V12 growth stage, a stand-alone ladder about 3.0 $\mathrm{m}$ high, was positioned and used to get the photographs above the canopy, also maintaining the distance of about $20 \mathrm{~cm}$ between camera and the plant. Each digital image was subsequently digitized and analyzed to obtain the LAI and CC using Green Crop Tracker Image Analysis software (Track code: 5470). The detailed description of the software and procedure can be found in Liu and Pattey (2010).

- Yield Components: Matured green maize cobs were harvested from an area $1 \mathrm{~m} \mathrm{x} 1 \mathrm{~m}$ from the center of each plot. Yield components of cob length, cob diameter, cob weight and total biomass were measured using a standard steel tape, digital vernier caliper and weighing scale. Cob weight and total biomass were converted to ton/ha.

- Water use efficiency (WUE): WUE was obtained as the ratio of crop yield to water applied according to the equation:

Where:

$$
\text { WUE, } \mathrm{kg} / \mathrm{ha} / \mathrm{mm}=\frac{\mathrm{Y}}{\mathrm{W}}
$$

$$
\begin{aligned}
& \mathrm{Y}=\text { yield }(\mathrm{kg} / \mathrm{ha}) \\
& \mathrm{W}=\text { water applied }(\mathrm{mm})
\end{aligned}
$$

\section{Irrigation Water Applied}

Irrigation application based on the different frequencies was scheduled by quantifying the time, in hours, to apply a given amount of water to the field by incorporating the soil water content at field capacity, the discharge of the emitters, the number of emitters per plot and plot area. The following equation was used to compute the equal time (hr) to irrigate the field.

$$
\mathrm{T}(\mathrm{hr})=\frac{\mathrm{SWC}_{\mathrm{FC}} \times \mathrm{A}}{\mathrm{D} \times \mathrm{N} \times \mathrm{I}_{\mathrm{E}}}
$$

Where $\mathrm{T}$ is the time to irrigate; $\mathrm{SWC}_{\mathrm{FC}}$ is soil water content at Field Capacity, $\mathrm{m}$; $\mathrm{A}$ is plot area, $\mathrm{m}^{2}$; $\mathrm{D}$ is emitter discharge, $\mathrm{m}^{3} / \mathrm{hr} ; \mathrm{N}$ is number of emitters per plot; $\mathrm{I}_{\mathrm{E}}$ is irrigation efficiency, taken as $95 \%$ for the drip irrigation system.

Irrigation was applied between 17:00 and 19:00 hours in the evening of each irrigation day to ensure adequate water redistribution in the soil during the night when there was limited or no evapotranspiration. The irrigation amount $\left(\mathrm{SWC}_{\mathrm{FC}} \times \mathrm{A}\right)$ was summed for the total number of days that irrigation was applied, considering the different frequencies (I4, I3, and I2).

Shortly after planting the maize crop in February, the rains started, though very erratic and not well distributed, thus the irrigation treatments became supplemental.

\section{Statistical Analysis}

Data collection was subjected to descriptive statistics and analysis of variance (ANOVA) and means were separated by the least significant difference (LSD) test at $5 \%$ level of significance. Regression analysis was run between soil bulk density versus water content and irrigation water applied versus yield and water use efficiency. All statistics were done in SAS (SAS Institute, version 8.1).

\section{Results and Discussion}

\section{Soil Physicochemical Properties, Rainfall} Distribution and Irrigation Water Applied

The results of some physicochemical properties of the $0-100 \mathrm{~cm}$ soil depth of the experimental area before the commencement of the study are shown in Table 1 . The $\mathrm{pH}$ ranged between 5.84 and 6.35 , which is slightly acidic in the subsurface layer, soil organic matter was low though highest $(0.57 \%)$ in the $0-20 \mathrm{~cm}$ surface layer and lowest $(0.19 \%)$ in the $20-40 \mathrm{~cm}$ subsurface layer. The total nitrogen was also highest $(0.73 \%)$ in the $0-20 \mathrm{~cm}$ surface layer and decreased with soil depth. Available $\mathrm{P}$ ranged between 4.8 and $17.0 \mathrm{mg} / \mathrm{kg}$. The soil particle analysis showed that the texture ranged between loamy sand in the

\begin{tabular}{|c|c|c|c|c|c|c|c|c|c|}
\hline Soil & $\mathrm{pH}$ & $\mathrm{EC}$ & $\mathrm{OM}$ & $\mathrm{TN}$ & Av. P & $\mathrm{K}$ & $\mathrm{Ca}$ & $\mathrm{Na}$ & $\mathrm{Mg}$ \\
\hline depth, cm & & $\mu \mathrm{s} / \mathrm{cm}$ & & & $\mathrm{mg} / \mathrm{kg}$ & & & & \\
\hline $0-20$ & 6.21 & 130.0 & 0.57 & 0.73 & 17.00 & 0.24 & 1.00 & 0.19 & 0.42 \\
\hline $20-40$ & 6.35 & 54.75 & 0.19 & 0.47 & 4.80 & 0.14 & 0.73 & 0.11 & 0.40 \\
\hline $40-60$ & 6.01 & 87.95 & 0.25 & 0.26 & 5.00 & 0.23 & 1.03 & 0.20 & 0.58 \\
\hline $60-80$ & 5.84 & 85.50 & 0.44 & 0.26 & 10.50 & 0.20 & 0.88 & 0.19 & 0.64 \\
\hline $80-100$ & 5.88 & 77.05 & 0.25 & 0.19 & 5.00 & 0.14 & 1.06 & 0.14 & 0.67 \\
\hline Soil & CEC & EA & Sand & Silt & Clay & Texture & $\mathrm{FC}$ & PWP & \\
\hline depth, cm & $\mathrm{cmol} / \mathrm{kg}$ & - & & $\%$ & & \multicolumn{4}{|c|}{$\mathrm{g} / \mathrm{g}$} \\
\hline $0-20$ & 1.60 & 0.15 & 79.68 & 13.59 & 6.37 & LS & 0.126 & 0.059 & \\
\hline $20-40$ & 1.68 & 0.06 & 69.00 & 19.00 & 12.00 & SL & 0.181 & 0.092 & \\
\hline $40-60$ & 2.40 & 0.13 & 49.20 & 15.77 & 35.03 & $\mathrm{~L}$ & 0.225 & 0.093 & \\
\hline $60-80$ & 2.53 & 0.10 & 44.83 & 15.52 & 39.65 & $\mathrm{SC}$ & 0.368 & 0.248 & \\
\hline $80-100$ & 2.05 & 0.08 & 58.91 & 12.19 & 28.90 & SCL & 0.290 & 0.188 & \\
\hline
\end{tabular}
uppermost layer to sandy clay loam in the deeper layer, with increase in clay content with soil depth (Table 1).

Table 1 . Some soil physicochemical properties of the study site

EC: electrical conductivity; OM: organic matter; TN: total nitrogen; Av. P: available phosphorus; K: potassium; Ca: calcium; Na: sodium; Mg: magnesium; CEC: cation exchange capacity; EA: exchangeable acidity; LS: loamy sand; SL: sandy loam; SCL: sandy clay loam; FC: field capacity; PWP: permanent wilting point the maize crop water requirement. 
The temporal distribution of rainfall during the growing cycle is presented in Figure 2. In this region, the onset of rainfall is normally in mid-March. However, this year was exceptional as the rain started in February, shortly after planting maize by irrigation. Despite the early onset of rainfall, the total amount of rainfall received during the growing cycle (between February and May) was about 500 $\mathrm{mm}$ which is below the total water requirement for maize, hence irrigation was still required to meet.

According to Reddy (2006), water requirement for maize is $600-700 \mathrm{~mm}$ for optimum growth and yield depending on the climatic conditions. Therefore, supplemental irrigation was designed towards meeting crop water requirement, thus the amount of water supplied by the different irrigation treatments are presented in Table 2.

\section{Soil Physical Properties and Plant Available Water}

The results of the soil water content (SWC) of the surface layer of the maize field are presented in Figure 3. Soil water content was similar (no significant difference) under the two maize varieties throughout the cropping cycle (Figure 3a). As expected, drip irrigation frequency increased the SWC, with more frequent irrigations (four times a week) (I4) having the significant $(\mathrm{P}<0.05)$ highest values of SWC during most period of the cropping cycle. There was marked increase in SWC in all treatments due to either irrigation or rainfall. For example, in treatment I2, the SWC increased by $149 \%$ on the 42 DAS while the increase was $163 \%$ on the 73 DAS. There was significant interaction $(\mathrm{P}<0.05)$ of irrigation frequency and maize variety on SWC except for the 42 (before irrigation), 70 and 71 DAS. After one month of sowing (28 DAS), treatment combinations of I4V1 and I2V2 had the highest and lowest SWC, respectively. At about eight weeks (54 DAS) after sowing, treatment I3V1 had the highest SWC while the lowest SWC was also obtained from I2V2. After 10 weeks (73 DAS), treatments I4V1 and I2V2 had the highest and lowest SWC, respectively. Thus, throughout the growing cycle, treatment combinations I2V1 and I2V2 had the lowest SWC (Figure $3 \mathrm{c}$ ). Furthermore, treatment I 2 had SWC below the permanent wilting point, the lower limit of plant available water, for the greater numbers days during the growing cycle while treatment I4 had SWC above field capacity, the upper limit of plant available water on more days compared to other treatments (Figure 3b). El-Hendawy et al. (2008) reported that drip irrigation frequency did affect soil water content and retained soil water, depending on soil depth. The authors found that the soil water content of the surface layer showed changes that are more dramatic and was below the permanent wilting point under less frequent irrigation treatments. Awe et al. (2017) also recorded significant effect of drip irrigation regimes on SWC from the same field under irrigated maize production. The significantly highest soil water content and better soil water distribution from I4 water application was due to higher soil water potential condition resulting from frequent soil wetting. According to Meshkat et al. (2000), irrigation regime with high frequency cause the soil surface to remain wet for long period and thus makes water available to crop when irrigation is off and no rain. Despite this advantage, over-irrigation results in water losses, increased vulnerability to diseases and environmental pollution arising from fertilizer loss (Fiebig et al., 2016).

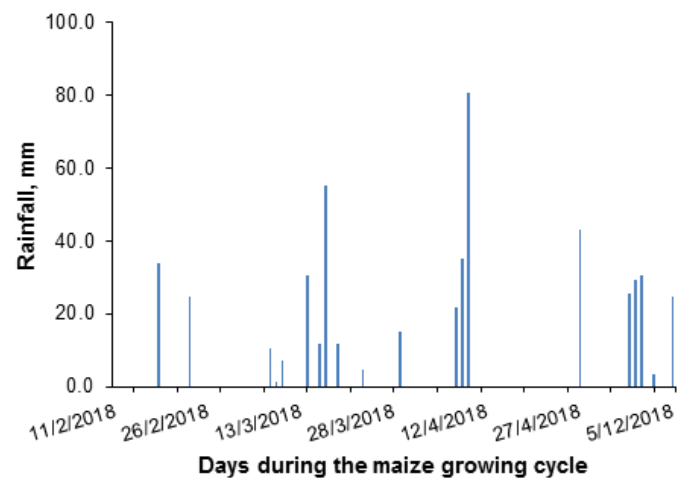

Figure 2. Temporal distribution of rainfall during the growing season.

Table 2. Irrigation water applied to the field under the different irrigation frequency.

\begin{tabular}{c|ccc}
\hline \multirow{2}{*}{ Irrigation } & \multicolumn{3}{|c}{ Treatments } \\
\cline { 2 - 4 } & $\mathrm{I} 4$ & $\mathrm{I} 3$ & $\mathrm{I} 2$ \\
\hline Amount, mm & 623.5 & 543.1 & 402.3 \\
\hline
\end{tabular}

I2: irrigation twice a week; I3: irrigation three times a week; I4: irrigation four times a week
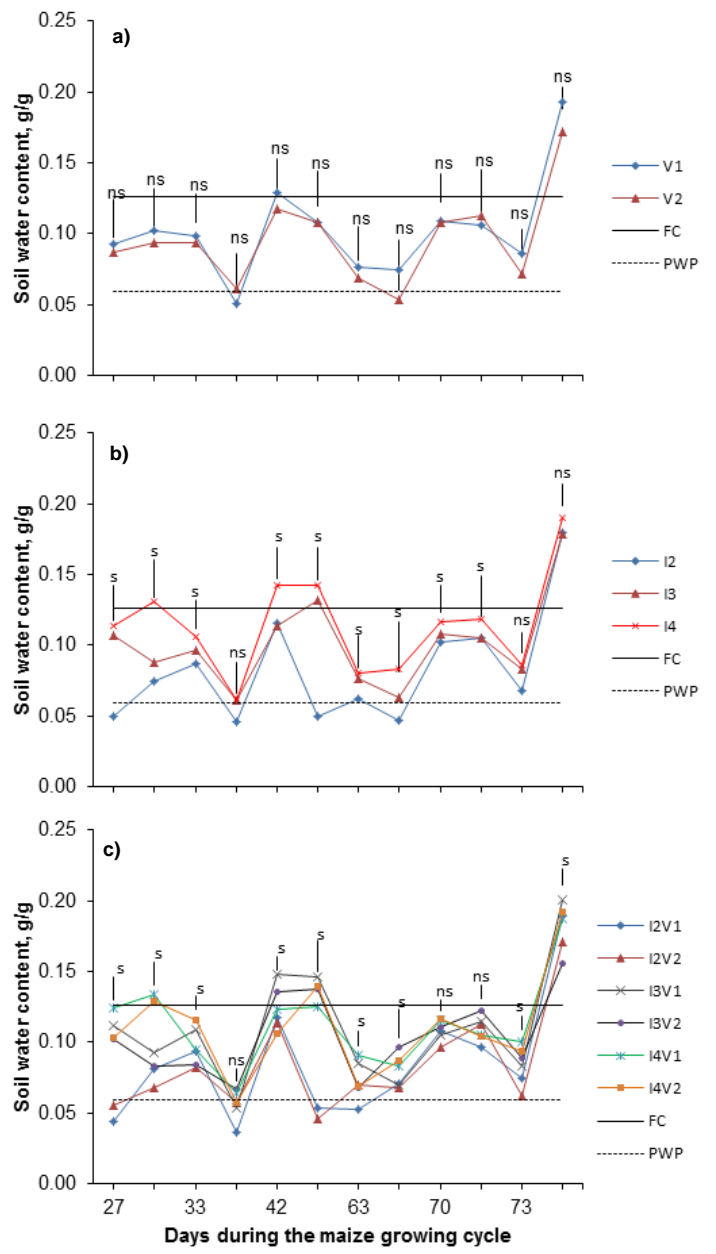

Figure 3. Temporal distribution of soil water content of the $0-20 \mathrm{~cm}$ surface of the maize field showing the effect of a) variety, b) irrigation regimes and c) interaction between irrigation and variety

V1: SAMMAZ-27 variety; V2: Oba Super-6 variety; I2: irrigation twice a week; I3: irrigation three times a week; I4: irrigation four times a week; FC: field capacity; PWP: permanent wilting point The vertical bars are the standard error of the mean. s: significant; ns: not significant at $5 \%$ level of probability by LSD test. 
On the other hand, low irrigation frequency may cause unstable moisture conditions for water in the soil, inhibits uptake by roots, and adversely affecting crop productivity. The significant effect of drip irrigation frequency and variety on SWC could be attributed to the differences in the growth pattern of the two maize varieties and degree of soil wetting by the different irrigation regimes during the growing season.

Figure 4 shows the results of the temporal distribution of bulk density (BD) of the surface layer of the maize field. Except for 52 and 64 (after irrigation event) days after sowing (DAS), soil bulk density differed significantly ( $\mathrm{p}<$ 0.05 ) under the two maize varieties. The average values of BD ranged between $1.24 \mathrm{~g} / \mathrm{cm}^{3}$ and $1.46 \mathrm{~g} / \mathrm{cm}^{3}$, with the highest values from maize variety V1. On the other hand, drip irrigation frequency did not significantly affect soil bulk density except on days 6 and 64, with irrigation 3 times weekly (I3) having the highest BD values throughout the growing cycle. Under the different irrigation treatments, BD ranged between $1.22 \mathrm{~g} / \mathrm{cm}^{3}$ and $1.52 \mathrm{~g} / \mathrm{cm}^{3}$. Except for day 64, there was no significant interaction $(\mathrm{P}<0.05)$ between irrigation frequency and maize variety on soil bulk density (Figure 4). The average BD ranged between $1.32 \mathrm{~g} / \mathrm{cm}^{3}$ and $1.46 \mathrm{~g} / \mathrm{cm}^{3}$, with treatments $\mathrm{I} 2 \mathrm{~V} 1$ and I3V2 having the highest and lowest values, respectively. There was an increase in soil BD at the end of the growing season. Irrespective of maize variety, irrigation every four and three times a week (I4 and I3) increased the soil BD by about $7 \%$ while irrigation twice a week (I2) increased soil BD by about $14 \%$. The increased $\mathrm{BD}$ at the end of the growing season is expected and attributed to soil reconsolidation as the soil tends to revert back to the original state after mobilization due to particle to particle rearrangement (Reichert et al., 2016; Reichert et al., 2017) as a result of alternate drying and wetting cycles. Furthermore, water uptake by plant roots promotes differential dehydration, with an increase in BD near the root zone as a result of soil adhesion (Young, 1998). The non-significant effect of irrigation regimes on soil BD throughout the growing season agrees with the findings of Abbas (2010) who reported that irrigation had no effect on soil BD. However, a significant effect of drip irrigation regimes on soil $\mathrm{BD}$ of the surface layer of the same field under maize trial in 2017 by Awe et al. (2017). This difference may be attributed to the prevailing climatic conditions and their complex interaction with the different management practices imposed.

The effects of irrigation frequency, crop variety and their interaction on soil hydraulic conductivity (Ksat) are shown in Table 3. Generally, the average values of Ksat increased over time.

Crop variety had no significant effect on Ksat however, there was a significant effect of drip irrigation frequency on Ksat. The interaction between drip irrigation and maize variety was significant on Ksat, with treatments I2V1 and I3V1 having the highest values at 2 and 8 WAS, respectively. The results contradicted the findings of Awe et al. (2017) who reported a decrease in Ksat over time from the same field. Soil saturated hydraulic conductivity (Ksat) is a transient soil property and its behaviour is related to the degree of soil compactness (Reichert et al., 2009), and is a function of the shape, arrangement, quantity, and continuity of soil pores (Mesquita and
Moraes, 2004), highly influenced by management practices and unseen features and processes below the soil surface.

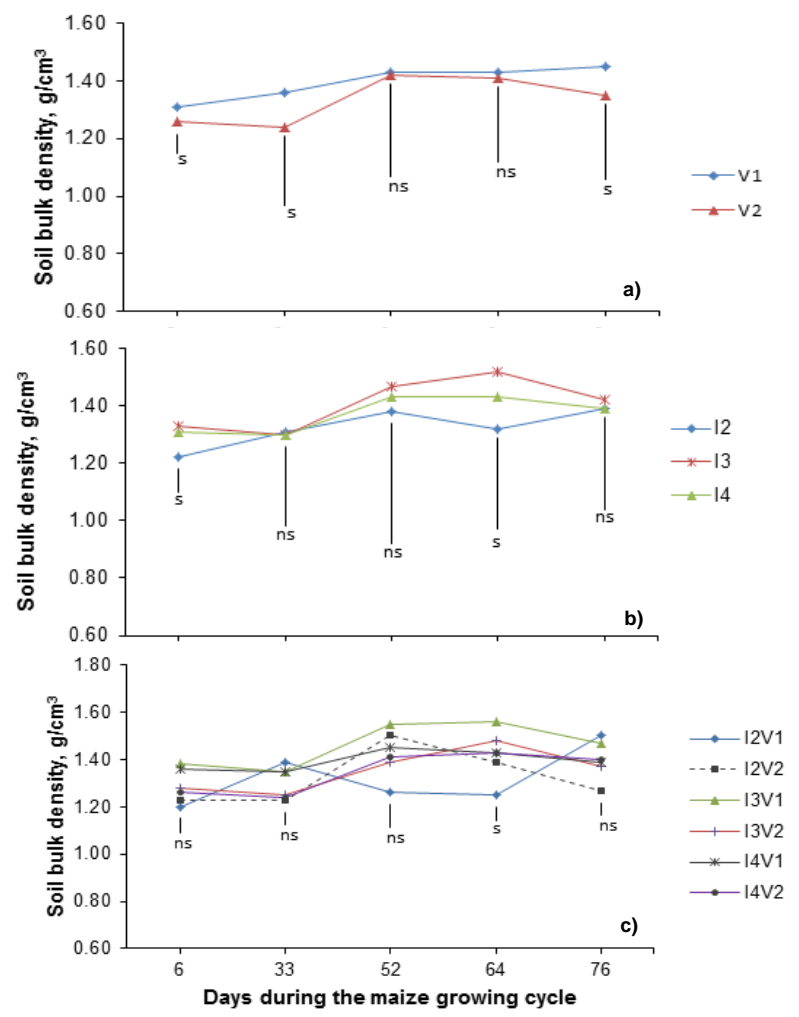

Figure 4. Temporal distribution of soil bulk density of the $0-20 \mathrm{~cm}$ surface of the maize field showing the effect of a) variety, b) irrigation regimes and c) interaction between irrigation and variety.

V1: SAMMAZ-27 variety; V2: Oba Super-6 variety; I2: irrigation twice a week; I3: irrigation three times a week; I4: irrigation four times a week. The vertical bars are the standard error of the mean. s: significant; ns: not significant at $5 \%$ level of probability by LSD test.

Table 3. Irrigation frequency, maize variety and their interactive effect on soil hydraulic conductivity (Ksat, $\mathrm{mm} / \mathrm{h}$ ).

\begin{tabular}{|c|c|c|}
\hline & 2WAS & VAS \\
\hline \multicolumn{3}{|c|}{ Variety } \\
\hline V1 & $29.57^{\mathrm{a}}$ & $61.90^{\mathrm{a}}$ \\
\hline $\mathrm{V} 2$ & $28.11^{\mathrm{a}}$ & $63.07^{\mathrm{a}}$ \\
\hline $\operatorname{LSD}_{p}<0.05$ & 22.05 & 33.24 \\
\hline \multicolumn{3}{|c|}{ Irrigation frequency } \\
\hline $\mathrm{I} 2$ & $37.14^{\mathrm{a}}$ & $52.97^{\mathrm{b}}$ \\
\hline I3 & $20.52^{\mathrm{c}}$ & $68.86^{\mathrm{a}}$ \\
\hline I4 & $28.05^{b}$ & $65.63^{\mathrm{a}}$ \\
\hline $\mathrm{LSD}_{\mathrm{p}<0.05}$ & 27.00 & 40.71 \\
\hline \multicolumn{3}{|c|}{ Interaction } \\
\hline I2V1 & $40.25^{\mathrm{a}}$ & $46.23^{c}$ \\
\hline $\mathrm{I} 2 \mathrm{~V} 2$ & $34.03^{\mathrm{b}}$ & $59.71^{\mathrm{bc}}$ \\
\hline I3V1 & $22.36^{\mathrm{c}}$ & $74.18^{\mathrm{a}}$ \\
\hline $\mathrm{I} 3 \mathrm{~V} 2$ & $18.67^{\mathrm{d}}$ & $63.54^{\mathrm{b}}$ \\
\hline $\mathrm{I} 4 \mathrm{~V} 1$ & $26.09^{b c}$ & $65.30^{\mathrm{b}}$ \\
\hline $\mathrm{I} 4 \mathrm{~V} 2$ & $31.62^{\mathrm{b}}$ & $65.96^{\mathrm{b}}$ \\
\hline $\operatorname{LSD}_{p<0.05}$ & 27.94 & 48.92 \\
\hline SEM & 3.58 & 5.82 \\
\hline
\end{tabular}

V1: SAMMAZ-27 variety; V2: Oba Super-6 variety; I2: irrigation twice a week; I3: irrigation three times a week; I4: irrigation four times a week. Values in a column with different letters differed significantly at $5 \%$ level of probability by least significant difference $\left(\mathrm{LSD}_{\mathrm{P}<0.05}\right)$ test. 
During land preparation, soil pores become distorted because of the disruption cause by soil mobilization by loosening the soil and breaking it up forming aggregates. According to Ghezzehei and Or (2000), the desired soil structure following tillage of agricultural soils is often unstable and susceptible to coalescence of aggregates and reduction of interaggregate porosity due to wetting and drying cycles. This could be the reason for the low Ksat shortly after land preparation. Conversely, the increased Ksat observed over time may be attributed to well-defined and stable natural and biopores over time. The added organic manure after land preparation may have increased soil aggregation, increase biological activities and promote pore space. There was no discernible trend among the different drip irrigation treatments on Ksat over time. The average values of soil Ksat were within the range (180 to $1800 \mathrm{~mm} \mathrm{~h}^{-1}$ ) considered ideal for efficient infiltration of surface water and drainage of excess water within the soil profile (Reynolds et al., 2003; Reynolds et al., 2008).

Soil available water for plant growth increased with increasing irrigation (Figure 5). Considering the soil water content at field capacity (FC) as the upper limit of available water and soil water content at permanent wilting point (PWP) as the lower limit of available water (below which water is unavailable), the available water in the $0-20 \mathrm{~cm}$ surface for root extraction during the growing period were $81.24 \mathrm{~mm}, 134.99 \mathrm{~mm}$, and $169.72 \mathrm{~mm}$ for I2, I3 and I4 irrigation treatments, respectively. The deficit in water of maintaining this surface at field capacity throughout the growing cycle was $161.57 \mathrm{~mm}, 107.81 \mathrm{~mm}$, and $73.04 \mathrm{~mm}$ for I2, I3 and I4 in that order while excess water at which water content was above the upper limit (FC) were $0 \mathrm{~mm}$, $17.82 \mathrm{~mm}$, and $30.50 \mathrm{~mm}$, respectively for I2, I3 and I4 treatments. Water deficit was high in $\mathrm{I} 2$ treatment because SWC was below the PWP at various during the growing cycle (Figure 3 ). According to Kaiser (2010), the amount of available water is dependent on the amount of rainwater and/or irrigation and its distribution in the soil profile. Therefore, the low amount of available water observed in I 2 is attributed to limited irrigations as well as losses to evaporation or drainage and absorption by plant roots. The days during which the water content was below the permanent wilting point, indicate unavailability of water to the maize crop.

Relationship between soil water content and bulk density

The relationship between the observed soil water content and bulk density of the surface layer is presented in Figure 6. A quadratic relationship exists between SWC and BD, with about $88.5 \%$ of the variation in SWC explained by BD. The SWC increased with an increase in BD to a point and then decreased with further increase in BD. Increase in soil BD causes the collapse of macropores and formation of more micropore volume which are responsible for water storage. The point at which the SWC was highest is called the optimum SWC (SWCopt) while the BD at this SWCopt is known as the maximum BD (BDmax). For this soil, the BDmax and SWCopt are $1.41 \mathrm{~g} / \mathrm{cm}^{3}$ and $0.12 \mathrm{~g} / \mathrm{g}$, respectively. The optimum water content is more or less corresponds to the FC of this layer (Table 1). In this study, the period during which the BD values were above the BDmax, especially in I4, had water content above the
SWCopt and such water was considered excess, it is subject to drainage and not available for plant use.

\section{Maize Growth Parameters}

The results of the effect of variety, irrigation and their interaction on maize growth parameters are presented in Table 4. Plant height ( $\mathrm{PH})$ did not differ between the two maize varieties throughout the growth cycle. Drip irrigation frequency did not significantly affect plant height until growth stage V12 (12 fully opened leaves), with I4 irrigation treatment having the highest value. Maize plant heights from I 2 and I3 treatment did not differ from each other. Similarly, the interaction effect between drip irrigation frequency and crop variety was not significant on PH until growth stage V12, with treatment I4V2 having the tallest plant.

Leaf area/plant significantly $(\mathrm{p}<0.05)$ differed between the two maize varieties and drip irrigation frequency. Maize variety V2 had the highest LA/plant at growth stage V3 (3 fully expanded leaves) but variety V1 surpassed variety V2 at leaf stages V9 and V12. The I2 irrigation treatment gave the highest LA/plant throughout the leaf stages although the values did not differ from that of I4 at V3 and V9 leaf stages. There was significant interaction between maize variety and irrigation frequency on leaf area, with treatment combinations of I4 versus V1 and V2 having plants with the highest LA/plant.
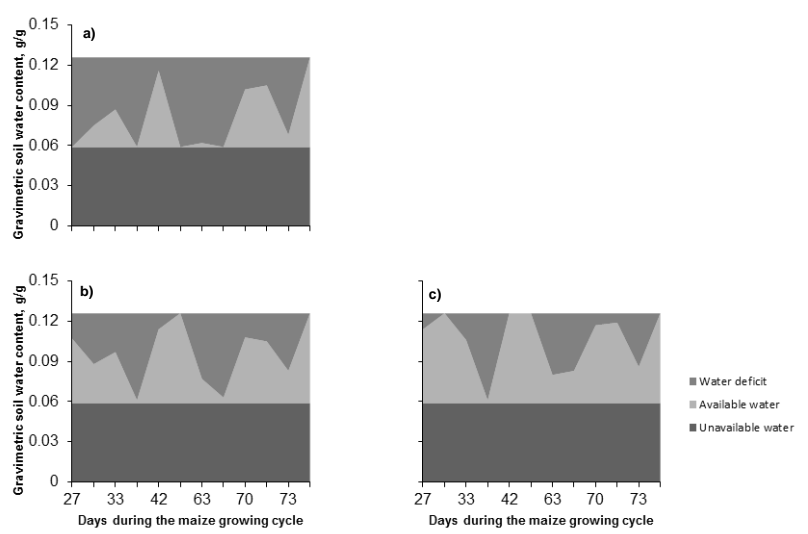

Figure 5. Plant available water of the $0-20 \mathrm{~cm}$ surface of the maize field under the different irrigation regimes a) two times irrigation per week (I2), b) three times irrigation per week (I3), and c) four times irrigation per week (I4).

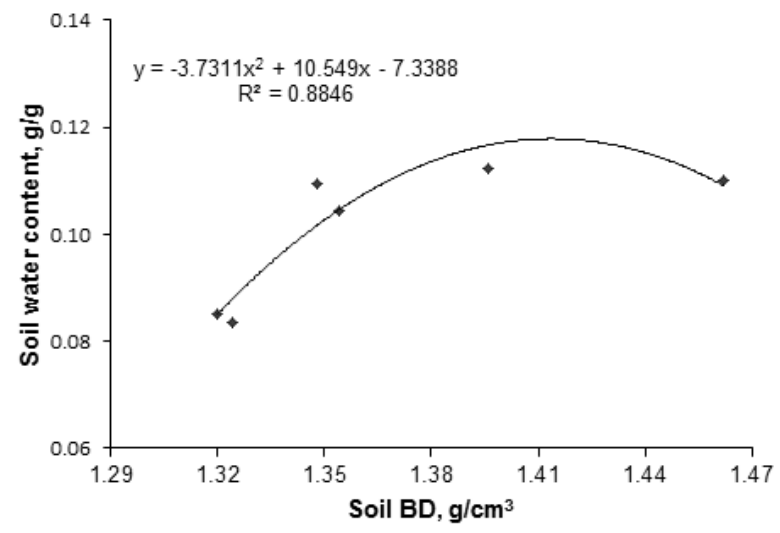

Figure 6. Relationship between soil water content and bulk density 
Table 4. Effect of variety and irrigation and their interaction on maize growth parameters.

\begin{tabular}{|c|c|c|c|c|c|c|}
\hline & \multicolumn{3}{|c|}{ Plant height, $\mathrm{cm}$} & \multicolumn{3}{|c|}{ Leaf area/plant, $\mathrm{cm}^{2}$} \\
\hline & 3 & 9 & 12 & 3 & 9 & 12 \\
\hline \multicolumn{7}{|c|}{ Variety } \\
\hline V1 & 16.23 & 166.14 & 239.51 & $30.93^{b}$ & $778.08^{\mathrm{a}}$ & $774.79^{a}$ \\
\hline $\mathrm{V} 2$ & 16.98 & 170.94 & 237.00 & $43.92^{\mathrm{a}}$ & $663.53^{b}$ & $680.24^{\mathrm{b}}$ \\
\hline $\mathrm{LSD}_{\mathrm{p}<0.05}$ & 3.2 & 11.1 & 12.4 & 6.6 & 92.9 & 100.7 \\
\hline \multicolumn{7}{|c|}{ Irrigation } \\
\hline $\mathrm{I} 2$ & 18.55 & 168.03 & $234.27^{b}$ & $40.96^{\mathrm{a}}$ & $740.38^{\mathrm{a}}$ & $969.26^{\mathrm{a}}$ \\
\hline $\mathrm{I} 3$ & 15.59 & 166.78 & $231.25^{\mathrm{b}}$ & $33.68^{\mathrm{b}}$ & $680.41^{\mathrm{b}}$ & $749.10^{\mathrm{b}}$ \\
\hline $\mathrm{I} 4$ & 15.68 & 170.83 & $249.25^{\mathrm{a}}$ & $37.64^{\mathrm{a}}$ & $741.69^{a}$ & $737.20^{\mathrm{b}}$ \\
\hline $\operatorname{LSD}_{\mathrm{p}<0.05}$ & 3.9 & 13.6 & 15.2 & 8.0 & 113.8 & 123.3 \\
\hline \multicolumn{7}{|c|}{ Interaction } \\
\hline $\mathrm{I} 2 \mathrm{~V} 1$ & 18.68 & 162.47 & $238.70^{b}$ & $36.44^{\mathrm{ab}}$ & $809.06^{\mathrm{ab}}$ & $743.63^{\mathrm{ab}}$ \\
\hline $\mathrm{I} 2 \mathrm{~V} 2$ & 18.42 & 173.58 & $229.83^{b}$ & $45.48^{\mathrm{a}}$ & $671.69^{c}$ & $648.89^{b}$ \\
\hline I3V1 & 14.78 & 169.65 & $242.33^{\mathrm{ab}}$ & $27.74^{\mathrm{b}}$ & $693.02^{\mathrm{bc}}$ & $778.33^{\mathrm{ab}}$ \\
\hline $\mathrm{I} 3 \mathrm{~V} 2$ & 16.40 & 163.90 & $220.17^{b}$ & $39.62^{\mathrm{ab}}$ & $667.80^{c}$ & $719.87^{\mathrm{ab}}$ \\
\hline I4V1 & 15.23 & 166.32 & $237.50^{\mathrm{ab}}$ & $28.62^{\mathrm{b}}$ & $832.15^{\mathrm{a}}$ & $802.43^{\mathrm{a}}$ \\
\hline I4V2 & 16.13 & 175.35 & $261.00^{\mathrm{a}}$ & $46.66^{a}$ & $651.22^{c}$ & $671.96^{\mathrm{ab}}$ \\
\hline $\operatorname{LSD}_{p<0.05}$ & 4.55 & 19.21 & 26.03 & 16.11 & 117.45 & 143.49 \\
\hline
\end{tabular}

V1: SAMMAZ-27 variety; V2: Oba Super-6 variety; I2: irrigation twice a week; I3: irrigation three times a week; I4: irrigation four times a week 3, 9 , 12: Maize at 3,9 and 12 fully-opened leaves; Values in a column with different letters differed significantly at $5 \%$ level of probability by least significant difference $\left(\mathrm{LSD}_{\mathrm{P}<0.05}\right)$ test.

Table 5. Irrigation frequency, maize variety and their interaction effect on leaf area index (LAI) and canopy cover (CC).

\begin{tabular}{|c|c|c|c|c|}
\hline & \multicolumn{2}{|c|}{ LAI } & \multicolumn{2}{|c|}{$\mathrm{CC}, \%$} \\
\hline & $2 \mathrm{WAS}$ & $8 \mathrm{WAS}$ & 2WAS & 8 WAS \\
\hline \multicolumn{5}{|c|}{ Variety } \\
\hline V1 & $0.45^{\mathrm{b}}$ & $4.15^{\mathrm{a}}$ & $20.00^{\mathrm{b}}$ & $97.13^{\mathrm{a}}$ \\
\hline $\mathrm{V} 2$ & $0.56^{\mathrm{a}}$ & $3.97^{\mathrm{a}}$ & $24.43^{\mathrm{a}}$ & $96.99^{\mathrm{a}}$ \\
\hline \multicolumn{5}{|c|}{ Irrigation frequency } \\
\hline $\mathrm{I} 2$ & $0.47^{\mathrm{b}}$ & $4.03^{\mathrm{a}}$ & $21.01^{b}$ & $97.02^{\mathrm{a}}$ \\
\hline $\mathrm{I} 3$ & $0.51^{\mathrm{a}}$ & $4.12^{\mathrm{a}}$ & $22.73^{\mathrm{a}}$ & $97.44^{\mathrm{a}}$ \\
\hline $\mathrm{I} 4$ & $0.53^{\mathrm{a}}$ & $4.03^{\mathrm{a}}$ & $22.71^{\mathrm{a}}$ & $96.94^{\mathrm{a}}$ \\
\hline $\mathrm{LSD}_{\mathrm{p}}<0.05$ & 0.05 & 2.12 & 1.7 & 5.93 \\
\hline \multicolumn{5}{|c|}{ Interaction } \\
\hline I2V1 & $0.46^{\mathrm{ab}}$ & $4.20^{\mathrm{a}}$ & $20.62^{\mathrm{ab}}$ & $97.72^{\mathrm{a}}$ \\
\hline $\mathrm{I} 2 \mathrm{~V} 2$ & $0.48^{\mathrm{ab}}$ & $3.86^{\mathrm{a}}$ & $21.39^{\mathrm{ab}}$ & $96.32^{\mathrm{a}}$ \\
\hline I3V1 & $0.45^{\mathrm{ab}}$ & $4.54^{\mathrm{a}}$ & $20.18^{\mathrm{b}}$ & $98.43^{\mathrm{a}}$ \\
\hline I3V2 & $0.58^{\mathrm{a}}$ & $3.71^{\mathrm{a}}$ & $25.28^{\mathrm{ab}}$ & $96.55^{\mathrm{a}}$ \\
\hline I4V1 & $0.43^{b}$ & $3.73^{\mathrm{a}}$ & $19.20^{\mathrm{b}}$ & $95.78^{\mathrm{a}}$ \\
\hline I4V2 & $0.62^{\mathrm{a}}$ & $4.33^{\mathrm{a}}$ & $26.62^{\mathrm{a}}$ & $98.09^{\mathrm{a}}$ \\
\hline $\operatorname{LSD}_{p}<0.05$ & 0.17 & 1.35 & 6.34 & 3.78 \\
\hline SEM & 0.026 & 0.168 & 0.97 & 0.48 \\
\hline
\end{tabular}

V1: SAMMAZ-27 variety; V2: Oba Super-6 variety; I2: irrigation twice a week; I3: irrigation three times a week; I4: irrigation four times a week, Values in a column with different letters differed significantly at $5 \%$ level of probability by least significant difference (LSD $<0.05)$ test. $\mathrm{SEM}_{\mathrm{P}}$ standard error of the mean

The Leaf Area Index (LAI) and Canopy Cover (CC) of the maize crop were evaluated at 2 and 8 WAS (Table 5). At 2 WAS, LAI and CC differed due to crop variety and drip irrigation frequency although LAI and CC from I3 did not differ from that of I4. Maize variety V2 gave the highest LAI and CC and there was a significant interaction effect between crop variety and drip irrigation frequency on both LAI and CC, with treatment I4V2 having the highest values. At 8 WAS, both drip irrigation and maize variety had no significant influence on both LAI and CC, neither was there any significant interaction effect (Table 5). The LAI obtained in this study compared well with that reported by Ibrahim et al. (2016) in a study on irrigation and fertigation scheduling under drip irrigation for maize crop in sandy soil in Egypt. Sampathkuma and Pandian (2010) in a study on the effect of fertigation frequencies and levels on growth and yield of maize in India also reported similar values of LAI. Leaf area index (LAI) influences photosynthetic radiation interception, water interception, latent and sensible heat fluxes, and $\mathrm{CO}_{2}$ exchange between terrestrial ecosystems and atmosphere and has been a key input descriptor or as an important state variable in many crop growth simulation models (Liu and Pattey, 2010). Crop cover fraction (CC) is a canopy structural descriptor that is associated with LAI. The near $100 \%$ CC obtained in this study showed the vigorous growth of the two maize varieties under the different irrigation regimes, indicating that very small fraction of the land will be available for evaporation process by limiting surface exposure to radiation. Thus, the soil mass, especially the surface layer, would remain wet for a longer period without irrigation or rain. 
Yield Components and Water Use Efficiency (WUE) Of Maize

Grain yield is a function of the interplay of various yield components such as 100-grain weight, ear length and so on. From Table 6, only maize cob length differed due to maize variety while irrigation regimes and their interaction were significant on all the yield components and water use efficiency. Maize yield components increased with an increase in irrigation water from I 2 to I4, with I4 treatment having yield $22 \%$ and $3 \%$ higher than treatments $\mathrm{I} 2$ and I3, respectively. On the other hand, WUE from I 2 was about $22 \%$ and $11 \%$ higher than in I4 and I3 treatments, respectively. The treatment combination of I4V1 gave the highest yield and yield components. The relationship between maize yield and soil physical properties are presented in Figure 7. All the soil physical properties, BD, Ksat and plant available water (PAW) showed indirect relationship with maize yield, indicating that high levels of the soil physical parameters will result to significant reduction in maize yield. Combining the three factors, the multiple regression equation was $\mathrm{Y}=3.57-0.484 \mathrm{LogKsat}$ $-0.595 \mathrm{BD}-0.076 \mathrm{PAW} ; \mathrm{R}^{2}=0.0497$. The low coefficient of determination between maize yield and the soil physical properties could be attributed to other factors which were not measured.

WUE was highest from variety $\mathrm{V} 1$ and the treatment combination of I2V1 (Table 6). The WUE decrease with an order of combined irrigation and variety levels from $\mathrm{I} 2 \mathrm{~V} 1=\mathrm{I} 2 \mathrm{~V} 2>\mathrm{I} 3 \mathrm{~V} 1=\mathrm{I} 3 \mathrm{~V} 2>\mathrm{I} 4 \mathrm{~V} 1>\mathrm{I} 4 \mathrm{~V} 2$.

The significant increase in yield and yield components from I 2 to I4 is attributed to the high amount of the irrigation water applied under treatment I4 resulted in more available soil water in the soil profile, which induced greater nutrients cycling and accessibility for absorption by plant roots. According to Ne Smith and Ritchie (1992) and Stone et al. (2001), the ideal conditions require that maize grows under high and nearly constant soil water potential, particularly during flowering and pollination stages. The results obtained were in agreement with the previous findings of Awe et al. (2017) with maize on the same soil. Other studies have also reported the greatest maize yield and yield components and lowest WUE from the highest irrigation levels (El-Hendawy, 2008; Kuscu et al., 2013; Shariot-Ullah et al., 2013).

\section{Relationship Between Irrigation Water Applied, Maize Yield and $W U E$}

Figure 8 shows the relationship between yield, WUE and irrigation water applied. The relationship between yield and water applied was linear and an increase in water supplied increases the yield by about $77 \%$ level of assurance. The linear increase indicates a direct relationship between yield and the amount of water applied. In this study, it may be that the optimum water application at which the yield is maximum and beyond which the yield decreases was not reached. Kuscu et al. (2013) obtained a quadratic relationship between maize yield and irrigation water applied in which increase in irrigation amount increased yield, more or less linearly to a point where that relationship was curvilinear reaching a maximum yield at an optimum water application. In line with our result, Payero et al. (2006) also reported a linear relationship between maize yield and irrigation water. An increase in water applied decreased WUE by $87 \%$ level of assurance. Other studies (e.g. Cui et al., 2015; Zhang et al., 2016; Zhang et al., 2018) have shown that yields increase first and then decrease, while water use efficiency decreases significantly with a certain amount of irrigation. The decrease in WUE with an increase in irrigation water stems from the fact that WUE was directly computed from the total water applied.

Table 6. Effect of variety and irrigation and their interaction on yield components and water use efficiency (WUE) of maize.

\begin{tabular}{|c|c|c|c|c|c|}
\hline & Cob length, $\mathrm{cm}$ & Cob dia., $\mathrm{cm}$ & Cob wt, ton/ha & Total bio, ton/ha & WUE kg/ha/mm \\
\hline \multicolumn{6}{|c|}{ Variety } \\
\hline V1 & $27.77^{\mathrm{a}}$ & 4.94 & 18.1 & 56.8 & 35 \\
\hline $\mathrm{V} 2$ & $25.62^{\mathrm{b}}$ & 4.99 & 17.1 & 55.7 & 33 \\
\hline $\mathrm{LSD}_{\mathrm{p}<0.05}$ & 0.99 & 0.26 & 8.8 & 3.24 & 1.60 \\
\hline \multicolumn{6}{|c|}{ Irrigation } \\
\hline $\mathrm{I} 2$ & $25.83^{\mathrm{b}}$ & $4.76^{\mathrm{b}}$ & $15.5^{\mathrm{b}}$ & $45.9^{c}$ & $38^{\mathrm{a}}$ \\
\hline I3 & $27.07^{\mathrm{a}}$ & $4.99^{\mathrm{a}}$ & $18.3^{\mathrm{a}}$ & $57.3^{\mathrm{b}}$ & $34^{\mathrm{b}}$ \\
\hline $\mathrm{I} 4$ & $27.18^{\mathrm{a}}$ & $5.15^{\mathrm{a}}$ & $18.9^{\mathrm{a}}$ & $65.5^{\mathrm{a}}$ & $30^{\mathrm{b}}$ \\
\hline $\mathrm{LSD}_{\mathrm{p}<0.05}$ & 1.21 & 0.32 & 1.08 & 3.97 & 2.00 \\
\hline \multicolumn{6}{|c|}{ Interaction } \\
\hline $\mathrm{I} 2 \mathrm{~V} 1$ & $26.61^{\mathrm{bc}}$ & $4.67^{b}$ & $15.3^{\mathrm{b}}$ & $49.2^{b}$ & $38^{\mathrm{a}}$ \\
\hline $\mathrm{I} 2 \mathrm{~V} 2$ & $25.06^{\mathrm{c}}$ & $4.85^{\mathrm{ab}}$ & $15.2^{\mathrm{b}}$ & $42.7^{b}$ & $38^{\mathrm{a}}$ \\
\hline I3V1 & $28.22^{\mathrm{ab}}$ & $4.93^{\mathrm{ab}}$ & $18.3^{\mathrm{a}}$ & $53.7^{\mathrm{b}}$ & $34^{\mathrm{ab}}$ \\
\hline I3V2 & $26.14^{\mathrm{c}}$ & $5.04^{\mathrm{ab}}$ & $18.3^{\mathrm{a}}$ & $61.0^{\mathrm{ab}}$ & $34^{\mathrm{ab}}$ \\
\hline $\mathrm{I} 4 \mathrm{~V} 1$ & $28.47^{\mathrm{a}}$ & $5.21^{\mathrm{a}}$ & $20.2^{\mathrm{a}}$ & $67.5^{\mathrm{a}}$ & $32^{\mathrm{b}}$ \\
\hline $\mathrm{I} 4 \mathrm{~V} 2$ & $25.67^{c}$ & $5.08^{\mathrm{ab}}$ & $17.7^{\mathrm{a}}$ & $63.5^{\mathrm{ab}}$ & $28^{\mathrm{b}}$ \\
\hline $\mathrm{LSD}_{\mathrm{p}<0.05}$ & 1.72 & 0.42 & 1.35 & 4.91 & 2.50 \\
\hline
\end{tabular}

V1: SAMMAZ-27 variety; V2: Oba Super-6 variety; I2: irrigation twice a week; I3: irrigation three times a week; I4: irrigation four times a week Cob dia: cob diameter; Cob wt: cob weight; Total bio: total biomass; WUE: water use efficiency Values in a column with different letters differed significantly at $5 \%$ level of probability by least significant difference $\left(\operatorname{LSD}_{\mathrm{p}<0.05}\right)$ test. 


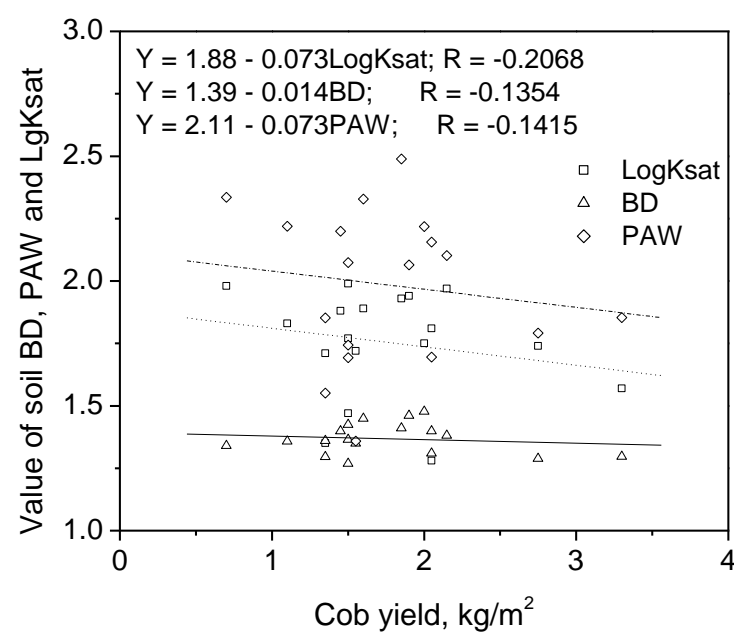

Figure 7. Relationship between maize yield and soil physical properties

PAW: plant available water; LogKsat: logarithm transformed soil saturated hydraulic conductivity; BD: bulk density, $\mathrm{R}^{2}$ : coefficient of determination.

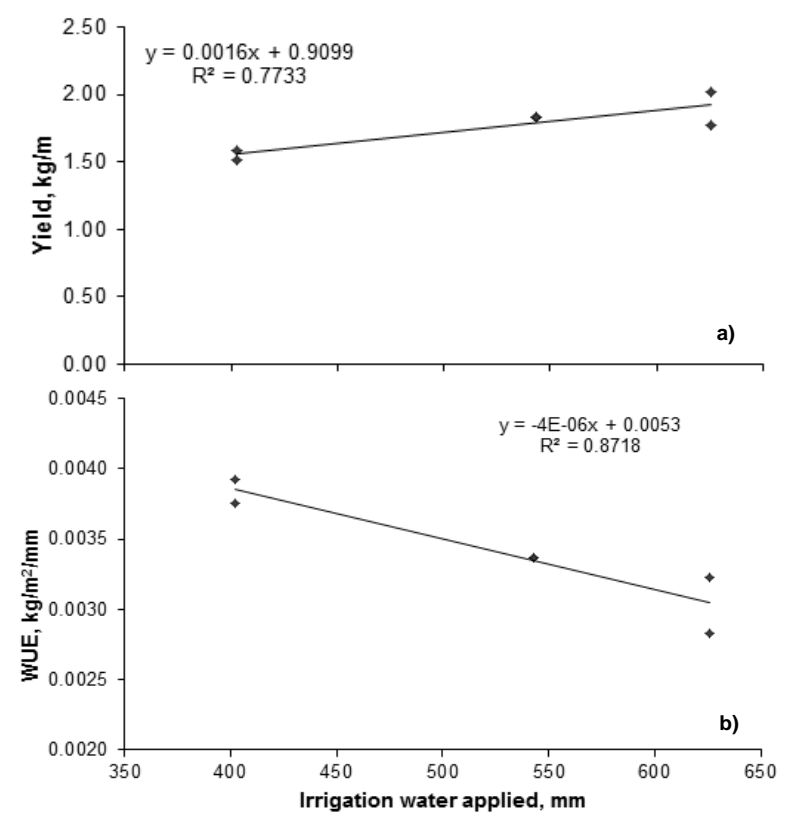

Figure 8. Relationship between irrigation water applied versus a) maize yield and b) water use efficiency (WUE).

\section{CONCLUSIONS}

There was an interactive effect of maize variety and irrigation frequency on SWC and Ksat but no effect on BD. Irrigating every two times a week (I2) gave the lowest soil available water.

Maize variety Sammaz-27 (V1) performed better than OBA-super-6 variety (V2) irrespective of the different irrigation conditions. Thus, this variety could be an option when considering crop-breeding program for large-scale maize production.

Treatment combination of I4V1 had the highest performance indices in terms of yield and yield components.
Therefore, Sammaz-27 maize variety (V1) and irrigation four times a week (I4) could be a suitable irrigation-variety combination for sustainable irrigation agriculture for maize production in this region. Further studies are required to establish the optimum water application for maximum maize yield under more irrigation frequency in this region.

\section{Conflict of Interest}

The authors hereby declare no conflict of interest

\section{References}

Abbas M. 2010. Effects of different levels of irrigation on maize yield, water use efficiency and soil properties under different sowing methods. MSc Dissertation in Soil Science, Institute of Soil and Environmental Sciences, faculty of Agriculture, University of Agriculture, Faisalabad, Pakistan, 106 pp.

Abd El-Hafez SA, El-Sabbagh AA, El-Bably AZ, Abou-Ahmed EI. 2001. Responses of maize crop to drip irrigation in clay soils. Alex. J. Agric. Res., 46(2): 153-159.

Abd El-Wahed MH, Ali EA. 2013. Effects of irrigation system, amounts of irrigation water and mulching on corn yield, water use efficiency and net profit. Agric. Water Manage, 120(31): 64-71.

Assouline S. 2002. The effects of micro drip and conventional drip irrigation on water distribution and uptake. Soil Science Sc. Am. J., 66(5): 1630-1636.

Awe GO, Fasina AS, Shittu OS, Jejelowo TA, Oparemi AD. 2016. Effects of drip irrigation frequency and N-fertilization on soil physical properties, yield and water use efficiency of cucumber (Cucumis sativus L.) in Ado Ekiti, southwestern Nigeria. Journal of Biology, Agriculture and Healthcare, 6(4): 32-46.

Awe GO, Fasina AS, Shittu OS, Omotoso SO. 2017. Irrigation and nutrient management for crop production: Maize (Zea mais) performance, resource use efficiency, and temporal variability of some soil physical properties. Journal, of Biology, Agriculture and Healthcare, 7(14): 33-47.

Blake GR, Hartge KH (1986). Bulk density. In Methods of Soil Analysis: Part 1- physical and mineralogical methods pp 377382.

Bouyoucous GJ. 1962. Hydrometer method improved for making particle size analyses of soils. Agronomy Journal 54(5):464465.

Cakir R. 2004. Effect of water stress at different development stages on vegetative and reproductive growth of maize. Field Crops Research, 89: 1-16.

Chen Z, Han Y, Ning K, Luo C, Sheng W, Wang S, Fan S, Wang Y, Wang Q. 2019. Assessing the performance of different irrigation systems on lettuce (Lactuca sativa L.) in the greenhouse. PLoS ONE, 14(2): e0209329. https://doi.org/ 10.1371/journal. pone.0209329

Clark L. 2004. Changes in properties of vineyard red brown earths under long-term drip irrigation, combined with varying water qualities and gypsum application rates. PhD Thesis, The University of Adelaide, Adelaide, Australia.

Cui HY, Hu FL, FangZS, Niu JY. 2015. Effects of irrigation amount and irrigation period on water requirement and yield of flax. Journal of Nuclear Agricultural Sciences, 29: 812819.

Currie DR. 2006. Soil physical degradation due to drip irrigation in vineyards: Evidences and implications. $\mathrm{PhD}$ Thesis, The University of Adelaide, Adelaide, Australia, 118 p. Available at: https://digital.library.adelaide.edu.au/dspace/bitstream/2440/ 58642/9/01 front.pdf. (12/05/2018). 
Deshmukh G, Hardaha MK. 2014. Effects of irrigation and fertigation scheduling under drip irrigation in papaya. $\mathrm{J}$ Agric. Search., 1(4): 216-220.

El-Hendawy SE, Hokam EM, Schmidhalter U. 2008. Drip irrigation frequency: the effects and their interaction with nitrogen fertilization on sandy soil water distribution, maize yield and water use efficiency under Egyptian conditions. J. Agron. Crop Sci., 194: 180-192.

El-Meseery AA. 2003. Effects of different drip irrigation systems on maize yield in sandy soil. In Proc. 11th Annual Conf. Society MISR of Agriculture Engineering Role in Reducing Losses and Maximizing Production, Cairo, Egypt, 2003. MISR J. Agric, 576-594.

Ezekiel O, Igbadun HE, Mudiare OJ, Oyebode MA. 2017. Development of deficit irrigation for maize crop under drip irrigation in Samaru-Nigeria. Agricultural Engineering International: CIGR Journal, 19(1): 94-107.

Fasina AS, Aruleba JO, Omolayo FO, Omotoso SO, Shittu OS, Okusami TA. 2005. Properties and classification of five soils formed on granitic parent materials of Humid southwest, Nigeria. Nigerian Journal of Soil Science, 15(2): 21-29.

Fiebig A, Dodd IC. 2016. Inhibition of tomato shoot growth by over-irrigation is linked to nitrogen deficiency and ethylene. Physiol. Plant., 156: 70-83.

Ghezzehei TA, Or D. 2000. Dynamics of soil aggregates coalescence governed by capillary and rheological processes. Water Resources Research 36(2): 367-379.

Ibrahim MM, El-Baroudy AA, Taha AM. 2016. Irrigation and fertigation scheduling under drip irrigation for maize crop in sandy soil. Int. Agrophysics, 30: 47-55. Doi: 10.1515/intag2015-0071.

Igbadun HE. 2012. Impacts of methods of administering growthstage deficit irrigation on yield and soil water balance of a maize crop. Nigerian Journal of Basic and Applied Science, 20(4): 357-367.

Hamblin AP. 1985. The influence of soil structure on watermovement, crop root-growth, and water-uptake. Advances in Agronomy, 38: 95-158.

Kara T, Biber C. 2008. Irrigation frequencies and corn (Zea mays L.) yield relation in Northern Turkey. Pakistan Journal of Biological Sciences, 11(1): 123-126.

Kuscu H, Demir AO. 2013. Yield and water use efficiency of maize under deficit irrigation regimes in a sub-humid climate. Philippine Agricultural Scientist, 96(1): 32-41.

Kuscu H, Karasu A, Oz M, Demir AO. 2013. Effect of irrigation amounts applied with drip irrigation on maize evapotranspiration, yield, water use efficiency and net returns in a sub-humid climate. Turkish Journal of Field Crops 18(1): 13-19.

Liu J, Pattey E. 2010. Retrieval of leaf area index from top-ofcanopy digital photography over agricultural crops. Agricultural and Forestry Meteorology, 150: 1485-1490.

Meshkat M, Warner RC, Workman SR. 2000. Evaporation reduction potential in an undisturbed soil irrigated with surface drip and sand tube irrigation. Trans. ASAE., 43(1): 79-86.

Muhumed MA, Jusop S, Sung CTB, Wahab EM, Panhwar Q. 2014. Effects of drip irrigation frequency, fertilizer sources and their interaction on the dry matter and yield components of sweet corn. Australian Journal of Crop Science, 8(2): 223 231
Ne Smith DS, Ritchie JT. 1992. Short and long-term responses of corn to a pre-anthesis soil water deficit. Agron. J., 84: 107113.

Payero JO, Steven M, Irmak S, Tarkalson DD. 2006. Yield response of corn to deficit irrigation in a semi-arid climate. Agric. Water Manage., 94: 895-908.

Reddy SR. 2006. Agronomy of field crops. $2^{\text {nd }}$ Ed. Kalyani Publishers, India.

Reichert JM, Suzuki LEAS, Reinert DJ, Horn R, Hakansson I. 2009. References bulk density and critical degree-ofcompactness for no-till crop production in subtropical highly weathered soils. Soil Till. Res., 102: 242-254.

Ritchie SW, Hanway JJ, Benson GO. 1986. How a corn plant develops. Special Report No. 48. Iowa State University of Science and Technology Cooperative Extension Service Ames, Iowa, USA, 24 pp.

Sampathkumar T, Pandian BJ. 2010. Effect of fertigation frequencies and levels on growth and yield of maize. Madras Agricultural Journal, 97(1-7): 245-248.

Saxena MC, Singh Y. 1965. A note on leaf area estimation of intact maize leaves. Indian Journal of Agronomy, 10: 437439.

Sezen SM, Yazar A, Eker S. 2007. Effect of drip irrigation regimes on yield and quality of field-grown bell pepper. In: Lamaddalena, N., Bogliotti, C., Todorovic, M., Scardigno, A. (eds.), Water saving in Mediterranean agriculture and future research needs. Options Méditerranéennes. Série B. Etudes et Recherches 1(56): 261-276.

Shariot-Ullah M, Mojid MA, Tabriz SS, Acharjee TK, Adham AKM. 2013. Growth and yield of three hybrid of maize varieties under different irrigation levels. Journal of Agric. Tech., 9(7): 1749-1758.

Soil Survey Staff (SSS) 2014. Keys to Soil Taxonomy. 12 Edition, USDA-Natural Resource Conservation Service, Washington CD, $372 \mathrm{pp}$

SPAW. 2020. Soil water characteristics, version 6.02.74, USA) available at http://hydrolab.arsusda.gov/soilwater/index.htm.

Stone PJ, Wilson DR, Jamieson PD, Gillespie. RN. 2001. Water deficit effects on sweet corn I: water use, radiation use efficiency, growth, and yield. Aust. J. Agric. Res., 52: 103113.

USDA. 2011. Grain: World markets and trade. Foreign Agriculture Service, Circular Series FG 09-11. Foreign Agricultural Service, United States Department of Agriculture, http:// www.fas.usda.gov/psdonline/circulars/ grain.pdf

Wang FX, Kang Y, Liu. SP. 2006. Effects of drip irrigation frequency on soil wetting pattern and potato growth in North China Plain. Agricultural Water Management, 79(3): 248264.

Young IM. 1998. Biophysical interactions at the root-soil interface: a review. Journal of Agricultural Science, 130: 1-7.

Zhang YH, Zhang Q, Xu XX, Li JP, Wang B, Zhou SL et al. 2016. Optimal irrigation frequency and nitrogen application rate improving yield formation and water utilization in winter wheat under micro-sprinkling condition. Transactions of the CSAE, 32: 88-95.

Zhang L, Yun J, Wang HB, Tang R. 2018. Effects of different irrigation treatments on growth characteristics and water use efficiency of maize. Journal of Irrigation and Drainage 37: 24-29. 